\title{
ENTREPRENEURSHIP DEVELOPMENT AND EMPLOYMENT GENERATION IN NIGERIA: A STUDY OF THE NATIONAL DIRECTORATE OF EMPLOYMENT
}

\author{
John N.N Ugoani \\ College of Management and Social Sciences, Nigeria \\ E-mail: drjohnugoani@yahoo.com
}

Grace I. Ibeenwo Akanu Ibiam Federal Polytechnic Unwana, Nigeria E-mail: gracyibeenwo@yahoo.com

Submission: 04/03/2015

Revision: 17/03/2015

Accept: 22/03/2015

\section{ABSTRACT}

The issues of entrepreneurship development and employment generation continue to receive high attention because of their impact on unemployment and poverty reduction in many parts of the world. The National Directorate of Employment was introduced by government in its efforts toward employment generation. In furtherance of attempts toward tackling unemployment, addressing issues of poverty and vulnerability and promoting inclusive finance at the grass-root levels, the Directorate has a Special Micro Empowerment Scheme, which is aimed at promoting social inclusion and job creation. Micro, Small and Medium enterprises such as water/beverage sales, shoemaking, shining, among other vocations account for about 99.6 percent of registered businesses in Nigeria by which about 63 percent of the labour force earn a living. The Directorate has created over 2.076 million employments since it was established. The NDEs one million job creation programme remains a wonderful idea in employment generation. The survey research method was used for the study. Surveys refer to an investigation of events that exist at the time of the research and connected with some problem situations that is felt over a wide area. Data analysis was 
INDEPENDENT JOURNAL OF MANAGEMENT \& PRODUCTION (IJM\&P)

http://www.ijmp.jor.br

v. 6 , n. 3, July - September 2015

ISSN: 2236-269X

DOI: 10.14807/ijmp.v6i3.308

done through Pearson's techniques. The result showed a very strong positive correlation between entrepreneurship development and employment generation. This is the aim of the study.

Keywords: Unemployment, Poverty, Shoemaking, Sure-P, Innovation, Chukwuma committee, Wonderful idea, Growth and Employment strategy, ILO, UNIDO.

\section{INTRODUCTION}

The economic and social development of any nation depends to a large extent on the emergency of a strong and vibrant private sector driven by entrepreneurship. The believe in this fact has spurned several initiatives by government to foster the creation of more micro, small and medium enterprises (MSMEs), strengthen the management capacity of the existing institutions and working out some modalities to provide easy access to capital for entrepreneurship development. One of the important agencies created by government to encourage entrepreneurship and create more employment is the National Directorate of Employment (NDE).

The programme believes that the ebb and flow of any meaningful business enterprise is usually highly dependent on the resilience of entrepreneurial activity often measured by an extraordinary predisposition to business venturing, the manifestation of high spirit for exceptional financial risk appetite, and a natural interest to the pursuit of productive investment. In Schumpeter's (1952) view in (AKANWA, 2006), innovation is the basis of entrepreneurship.

Innovation includes the doing of new things and the doing of things that are already being done in a new way. He developed his concept which is now elevated to a school of thought. This school believes in two things - entrepreneurial role, and managerial role. The entrepreneurial role involves making strategically important and innovative decisions; managerial role involves maintaining routine operations of the enterprise.

Fortunately, this coincides with the contemporary view regarding an entrepreneur as a person who makes strategic and innovative decisions in the dayto-day management of a business. Consequently, the theory of profitability has often been used to explain entrepreneurship earnings (AKANWA; AGU, 2005, DEBELAK, 2006). 
INDEPENDENT JOURNAL OF MANAGEMENT \& PRODUCTION (IJM\&P)

http://www.ijmp.jor.br

v. 6 , n. 3, July - September 2015

ISSN: 2236-269X

DOI: 10.14807/ijmp.v6i3.308

Entrepreneurship is the process of creating value by pulling together a unique package of resources to exploit an opportunity. Because the entrepreneur never controls all the necessary resources, pursuing the opportunity requires bridging the resource gap. Such a process requires a series of choices, which must be made in a manner, which is both internally consistent and externally appropriate to the market. Since the market drives entrepreneurship, the entrepreneurship can therefore be seen as a catalyst that is highly innovative along with market needs.

In doing so, the entrepreneur must translate careful choices into economic performance, deal with the problems that arise as the enterprise grows, and decide when to harvest the venture. The entrepreneur must carefully plan and then gradually implement the process (HOFER; CHARAN, 1984). In an emerging market like Nigeria, a focus on entrepreneurs, entrepreneurship and the enterprise is critical within the important context of the necessary programming for sustainable human development and the creation of employment (MATANMI, 2006).

Entrepreneurship is directly linked to employment because it is a unique process that creates opportunities of employment. Employment as the word implies means to give work to somebody, usually for payment. To this extent therefore, employment is an act of employing somebody for a wage or payment for his services. Employment also implies those people who are engaged either permanently or temporarily in a productive venture for a payment. The payment may be daily, hourly, weekly or monthly.

In contrast, unemployment is a situation in which some people who are qualified, ready, willing and able to work do not find work to do. It is also a situation where some people who fall within the ages of the working population, capable and willing to work are unable to secure befitting jobs to do. Since unemployment constitutes one of the problems facing many nations, especially the developing nations like Nigeria, governments tend to focus much attention on programmes and methods of combating it (UWAZIE, 2006).

The Federal Government of Nigeria (FGN) launched the NDE programme in 1986 as a bold strategy for dealing with mass unemployment. The programme has four core components including: National Youth Employment and Vocational Skills Development Programme, Small Scale Industries and Graduate Employment 
INDEPENDENT JOURNAL OF MANAGEMENT \& PRODUCTION (IJM\&P)

http://www.ijmp.jor.br

v. 6 , n. 3, July - September 2015

ISSN: 2236-269X

DOI: 10.14807/ijmp.v6i3.308

Programme, Agricultural Sector Employment Programme and Special Public Works Programme.

These were created to take care of the majority of Nigerian Youths who have no productive and marketable skills. Since Nigeria is supposedly an agrarian based economy, the agricultural sector employment programme of NDE is designed for graduates of agricultural discipline who are interested in self-employment in agriculture. The programme is executed in collaboration with state governments. According to NDE (1986), the state provides about 500 hecters of farmland for the programme each year. After the necessary screening of applicants, the NDE places 100 or more graduate candidates as participants in the scheme.

Each participant is given 5 hecters of cleared farmland and a certain loan amount to start, through which the NDE seeks to promote micro, small and medium enterprises, vocational skills development, promote rural employment, among other entrepreneurship activities. All over the globe, a major problem of the entrepreneur and an obstacle to entrepreneurship process has often been lack of access to finance for entrepreneurship development. According to the World Bank (2009), many middle-class people in poor countries are entrepreneurial, most run smallscale business with few asset.

Family members supply labour, paid staff are few. Obtaining start up finance is not always simple or easy, however, even for successful entrepreneurs. Business loan application can be onerous, often requiring detailed financial projections and business plans. Proof of employment, letters of reference, or other documents are required in countries like Nigeria, Liberia and Zambia. New entrepreneurs and small enterprises typically lack the expertise to prepare detailed business plans and are frequently unable to access credit through the traditional financial institutions.

The NDE perspective did not take cognizance of the fact that there may not be any reasonable entrepreneurship and employment generation without adequate finance. For example, at the inception of the NDE, a loan of N11500.00 was approved for those going into crop farming. Out of the loan, the sum of N7325.00 was paid out to the supplier of seeds, farm implements, pesticides, fertilizers, storage crops and land preparation. 
INDEPENDENT JOURNAL OF MANAGEMENT \& PRODUCTION (IJM\&P)

http://www.ijmp.jor.br

v. 6 , n. 3, July - September 2015

ISSN: 2236-269X

DOI: 10.14807/ijmp.v6i3.308

The remaining N4175 was for wages of the farmland and the participant's monthly stipend of N150. The NDE strategy in this way never helped in entrepreneurship and employment generation. This situation has resulted into the establishment of other schemes like the micro small and medium enterprises scheme, small and medium enterprises development agency of Nigeria, to drive entrepreneurship development (ED) and employment generation (EG) in Nigeria.

Otti (2014) reports that Anyaoku, while bemoaning the high unemployment rate among youths in the country describes it as a big drain on national economy, and stressed the need for entrepreneurship among youths. Entrepreneurship is a process of innovation that discovers new and more valuable combinations of resources, which result to the exploitation of profitable business opportunities and the creation of employment.

Nigeria today needs young graduates that are entrepreneurially bent to float businesses based on their specific knowledge of time and place. For example, graduates of Agriculture should be able to come up with business ideas to float entrepreneurial businesses that would create jobs in animal husbandry and dairying, fisheries, horticulture and allied sectors.

Also, graduates of finance and accounting should be able to generate ideas for entrepreneurial ventures that would solve multiple financial problems, such as reliable and integrated credit information database. In the same vein, professions like medicine, engineering, architecture, insurance, pharmacy, real estate, etc. are all yearning for knowledgeable entrepreneurship development. What is needed is necessary entrepreneurial spirit among youths to save them from the debilitating frustration of unemployment (ISIMOYA, 2012).

Aganga, (2012) hints that Nigeria is encouraging entrepreneurship development through micro, small and medium enterprises (MSMEs). He says: "We have since the beginning of this administration strategically positioned small businesses to drive the economy. The recent data undertaken by the Small and Medium Enterprises Development Agency of Nigeria (SMEDAN) and the National Bureau of Statistics (NBS) put the micro, small and medium businesses in the region of 17.3 million across the country with total employment in the sector put at about 32 million and contribution of about 45 percent to the GDP. 
INDEPENDENT JOURNAL OF MANAGEMENT \& PRODUCTION (IJM\&P)

http://www.ijmp.jor.br

v. 6 , n. 3, July - September 2015

ISSN: 2236-269X

DOI: 10.14807/ijmp.v6i3.308

"We have a market with 167 million people. In fact, the strategy for job creation in most developed economies is based on the SME sector. He assures that assuming that if only half of the $17.3 \mathrm{~m}$ MSMEs create a job each every year that is about 8 million "That is why developed and developing economies are basing their plan on SMEs. According to Aganga (2012), the country has also developed a new SME policy. He alerts that one of the major challenges confronting small and growing businesses (SGBs) is access to competitive market both locally, regionally and internationally and that a new impetus must be generated to expand SGBs horizon.

He opines that for the SGBs or MSMEs the mentality has to change from starting a business to growing a business, like Bill Gates, Aliko Dangote, and others who started small and expanding because they have a vision. To provide finance for entrepreneurship development the Central Bank of Nigeria (CBN) says it will set aside N600billion for onward lending to small holder farmers as financial inclusion strategy that aims to ensure that a clear agenda is set for increasing both access to and use of financial services within the defined timeline which is by 2020 . The fund will be disbursed through Micro Finance Banks (MFBs).

MFBs being a subsector that is close to the primary producers, processors and distributors of agricultural products are recognized to participate in the distribution of founds to MSMEs against the often unwillingness of the conventional banks to support entrepreneurship. The MFBs will collaborate with the Nigeria Incentive Based Risk Sharing System for Agricultural Lending (NIRSAL) for easy access to entrepreneurship credit. NIRSAL offers three main products for the development of entrepreneurship in the agricultural sector.

First, it offers credit risk guarantees for loans and credits issues by a range of financial services providers to participants in the agribusiness value chain. Its guarantees cover between 30 to 70 percent of loan exposure for activities related to crop, livestock and aquaculture production, processing and distribution. It has no limit on the size and duration of the guarantee, and can also take foreign currency based risks via swap arrangements.

Secondly, it offers strategic investment advice to value chain participants and local state and federal governments. Such advice includes how to make the local 
INDEPENDENT JOURNAL OF MANAGEMENT \& PRODUCTION (IJM\&P)

http://www.ijmp.jor.br

v. 6 , n. 3, July - September 2015

ISSN: 2236-269X

DOI: 10.14807/ijmp.v6i3.308

market more investment friendly, improve key infrastructure, and drive job/wealth creation using agribusiness. And thirdly, financial and structuring advice to investors and value chain stakeholders seeking a particular value chain such as cassava chip export or rice production. (MOSES-ASHIKE, 2012).

Over $1.4 \mathrm{~m}$ jobs were created through MSMEs in 2012, according the Small and Medium Enterprises Development of Nigeria (SMEDAN) (AGBOOLA, 2012). According to Afolabi (2014) in the last five years, the MSMEs sector accounted for about 99.6 percent of the registered businesses in the country by which 65 percent of the labour force earn a living. About 35.7 percent of the total sales and value added in the manufacturing sector also come from MSMEs as well. Thus, entrepreneurship, through MSMEs, contributes to the creation of wealth, employment and income generation, both in rural and urban areas, and ensuring a more equitable income distribution.

They also provide the economy with a continuous supply of ideas, skills and innovations necessary to promote competition and the efficient allocation of scarce resources. Despite theories and practical development of indigenous MSMEs and governmental policies and programmes on entrepreneurship, resulting in frequent improvements, changes, and modifications of programme, the broad objective of reducing unemployment through entrepreneurship is yet to be achieved. It would appear that interested stakeholders efforts could not produce effective result due to lack of disciplined behaviour by entrepreneurs and officials charged with the execution of government entrepreneurial assistance programmes. The missing link is general lack of business ethics (OGUNDELE. 2006) Snyder, et al, 1983, Stevenson and Gumpert, 1985 Leap Africa, 2006).

To address the issue of unemployment government plans to create $5 \mathrm{~m}$ jobs by 2015 through the National Enterprises Development Programme (NEDEP) and the Nigerian Industrial Revolution Plan (NIRP). The aims of the programmes will be actualized through the establishment of micro, small and medium enterprises in the 774 local government areas based on comparative and competitive advantages. NEDEP was developed with the objective of addressing the major challenges militating against MSMEs growth and development across the country to generate employment (MASARI, 2014). 
INDEPENDENT JOURNAL OF MANAGEMENT \& PRODUCTION (IJM\&P)

http://www.ijmp.jor.br

v. 6 , n. 3, July - September 2015

ISSN: 2236-269X

DOI: 10.14807/ijmp.v6i3.308

According to Aganga (2013), the Ministry of Industry Trade and Investment through SMEDAN processed over 1000 business plans by various MSMEs cooperatives across the country for funding adding that the target was to process about 10,000 business plans from MSME co-operatives in 2013 as employment generation strategy. Lack of employable skills is a major contributing variable to the problem of unemployment in all parts of the world and especially in Nigeria.

The issue is compounded because the educational system run in the country places emphasis on liberal education rather than acquisition of vocational skills, which would prepare individuals for entrepreneurship ventures that, would help in self-employment and employment generation generally.

Consequently in frantic efforts to seek a way out of the problem the Federal Government constituted the Chukwuma Committee in 1986 to consider appropriate strategies for dealing with mass unemployment problem in the country under the Ministry of Employment Labour and Productivity and the work of the Chukwuma Committee, among others gave birth to the NDE. Between 1987 and 1996, about $1.90 \mathrm{~m}$ Nigerians benefited from the NDE skills acquisition, skills that helped in entrepreneurship development and employment generation (ADEBISI; ONI, 2012, NZENWA, 2000, ADAMS, et al, 2011, NDUJIHE, 2015).

\subsection{Statement of the problem}

The National Directorate of Employment as a mechanism for entrepreneurship development and employment generation appears to focus more on youth-oriented activities. Especially there is high emphasis on skill acquisition centres. While these are important for entrepreneurship growth, it offers little opportunities for employment generation in view of Nigeria's population density and the few members of people engaged in NDE centers.

The NDE has no serious arrangement for the finance of start-up and even existing entrepreneurial activities such that would ensure their sustainability and capacity to generate employment. The provision of paltry loans for participants in its agricultural activities manifested more in such farms being over grown by weeds and even taking over the farmers inside the farms, instead, due to lack of adequate finance to prosecute the business. Unemployment rate continues to rise in the country. 
INDEPENDENT JOURNAL OF MANAGEMENT \& PRODUCTION (IJM\&P)

http://www.ijmp.jor.br

v. 6 , n. 3, July - September 2015

ISSN: 2236-269X

DOI: 10.14807/ijmp.v6i3.308

Osehobo (2012) reports the minister of youth's development as declaring that about 67 million youths were certified jobless, of the figure, 80 percent do not possess university degrees. The minister attributes the high rate of unemployment to years of failure at different levels, explaining that "lack of job is a consequence of lack of skills". And to bridge the skills gap the NDE through its training programmes seeks to equip participants with the necessary competencies for self-employment and other opportunities.

Despite the existence of different programmes in addition to the NDE, finance remains a major problem of entrepreneurship development in Nigeria. To minimize the problem, each state of the federation has approval to access N2bn from the CBN through the Micro, Small and Medium Enterprise Development Fund (MSMEDF). This is based on the fact that for any economy to grow, it must be private sector based and driven by MSMEs, which are more active in the economic development of any country (OTABOR, 2014) The NDE seeks to reduce youth unemployment as the issue is a subject that is common in Nigeria and statistics show that about 300000 Nigerians graduate from tertiary institutions yearly into the labour market with little or no job opportunities (ONYEKAKEYA, 2014, OKOJIE, 2011).

\subsection{Objective of the Study}

The study was designed to explore the relationship between entrepreneurial development and employment generation in view of the importance of the variables in the economy of any country.

\subsection{Delimitation of the study}

The study was delimited to a cross-section of the population in Aba, Nigeria. The choice of $\mathrm{Aba}$ is unique in view of the high number of entrepreneurs in the city.

\subsection{Significance of the study}

The study will provide insights on entrepreneurship development programmes in Nigeria and particularly the workings of the NDE. Students, researchers and the several public may find such information helpful.

\subsection{Limitation of the study}

The study was acutely constrained by lack of any research grant window. 


\subsection{Hypotheses}

To achieve the objective of the study, two hypotheses were formulated and tested at 0.05 level of significance.

Ho: There is no relationship between entrepreneurship development and employment generation.

$\mathrm{Hi}$ : There is a relationship between entrepreneurship development and employment generation.

\section{LITERATURE REVIEW}

The National Directorate of Employment is one of the Federal Government's effort towards encouraging the survival and development of small-scale businesses. The programme is especially charged with provision of skills and loans to enable young graduates establish their own businesses. The programme sparked off the highest number of small-scale businesses throughout the country. Under the programme, the small business owners enjoy low taxes, free technical advice and other support services provided by the Federal Government to enhance employment generation. (OKENWA, 1999).

According to Adebisi and Oni (2012), the philosophy of the NDE is selfenterprise, which emphasizes self-employment and self-reliance in preference to wage employment. This philosophy is pursued through policy planning and wellarticulated programmes of Rural Employment Promotion (REP), Vocational Skills Development Programme (USD), Special Public Work Programme (SPWP), and Small Scale Enterprise Programme (SSE).

These programmes are set up across the nation in an effort to alleviate unemployment problems in the nation. The NDE does not leave the disabled out of its programmes. The disabled work scheme is designed to enable the disabled acquire skills, produce marketable products that will keep them gainfully employed.

\subsection{Four major NDE Programmes}

The four major vehicles of the NDE programme are (a) National Youth Employment and Vocational Skills Development Programme (b) Small Scale Industries and Graduate Employment Programme, (c) Agricultural Sector Employment Programme and (d) Special Public Works Programme. 
INDEPENDENT JOURNAL OF MANAGEMENT \& PRODUCTION (IJM\&P)

http://www.ijmp.jor.br

v. 6 , n. 3, July - September 2015

ISSN: 2236-269X

DOI: 10.14807/ijmp.v6i3.308

\section{a) National Youth Employment and Vocational Skills Development Programme.}

This programme takes care of the majority of Nigerian Youths who have no productive and marketable skills. The programme is run through the national open apprenticeship scheme, waste to wealth scheme, schools on wheels scheme and disabled work scheme. Under the programme the participants are required to register with the Federal Ministry of Employment, Labour and Productivity's local labour exchanges before being accepted as trainees when they have completed their period of apprenticeship thereby acquiring the necessary skills, they become potential candidates for employer's consideration and absorption. Alternatively, those who can go into self-employment are encouraged to do so.

\section{b) Small Scale Industries and Graduate Employment Programme}

The SSIGEP is designed by NDE to assist the unemployed people set-up their own businesses. This is done after it has conducted courses in entrepreneurship and its job creation loan scheme. The participant is required to submit a feasibility study of the intended venture, which is studied by a bank. The loan for the venture where given by a bank is collateralized by the applicants' degree certificates and guaranteed by NDE.

Such loan is repayable within a period of 5years at an interest rate determined by the Central Bank of Nigeria. The NDE is disposed to such small businesses as candle making, soap and detergent making, restaurants, agricultural production. Refuse collection, printing and publishing, fashion designing, textiles and garment making, among others.

\section{c) Agricultural Sector Employment Programme}

This programme is designed to provide self-employment in the agricultural sector. The ASEP is run in collaboration with state governments who provide the land. Applicants registered for this programme is allocated 5 hecters of cleared farmland to take off and with an agreed amount of loan. This is an important component of the NDE programme.

According to Olayinka, (2014) NDE says it will establish one agricultural park each in the Northern and Southern parts of the country to generate employment in the agricultural sector. According to NDE, it has empowered a total of number of 177,168 participants in the last two years. The timeframe, which covers the entire 
INDEPENDENT JOURNAL OF MANAGEMENT \& PRODUCTION (IJM\&P)

http://www.ijmp.jor.br

v. 6 , n. 3, July - September 2015

ISSN: 2236-269X

DOI: 10.14807/ijmp.v6i3.308

2013 up to September, 2014 shows that 48,558 persons benefitted from the training in vocational skills development while public works and community/technical skills development attracted 460 persons 2,900 benefitted from the agricultural skills and rural development, and 26102 benefitted from the entrepreneurial/business skill development, graduate transient job creation attracted 6,880 persons while 271 enrolled for the enterprises created by graduates and artisans.

14800 participants took part in its micro enterprises enhancement scheme while women and vulnerable empowerment scheme attracted 1105 and employment counselling and job linkages recorded 76,092 participants. In furtherance of its efforts towards tackling unemployment, addressing issues of poverty and vulnerability and promoting inclusive finance at the grassroots levels the NDE has a new Scheme called Special Micro Empowerment Scheme (SMES) which is aimed at promoting social inclusion and job creation.

Basically, the new scheme seeks to assist the poor and vulnerable persons (petty traders, artisans, women, widows, orphans, internally displaced persons, physically challenged persons, etc.) and establish/manage or boost their own micro enterprises. The micro enterprises being promoted includes: shoemaking, vegetable oil extraction, water/beverage sales, potatoes/plantain frying, among others. The NDE lists low funding level as a major stumbling block as it affects the capacity building for personnel, curtail programme expansion for full capacity utilization, restrain capacity building for skills acquisition training centres through facility upgrading to meet international standards.

\section{d) Special Public Works Programme}

This programme seeks to give temporary employment to a pool of the unemployed in maintaining public work. The state governments in collaboration with the NDE identify projects to which participants are deployed. These include: construction and maintenance of roads, buildings and other infrastructure, tree planting, environmental sanitation, land clearing and other farm support services.

\subsection{NDE Training Component}

According to Adebisi and Oni (2012), the core issue in providing relevant training is to identify what the real training needs are. Therefore, to make training count it must be related directly to the needs of the people. They opine that an 
INDEPENDENT JOURNAL OF MANAGEMENT \& PRODUCTION (IJM\&P)

http://www.ijmp.jor.br

v. 6 , n. 3, July - September 2015

ISSN: 2236-269X

DOI: 10.14807/ijmp.v6i3.308

important characteristic of technical and vocational education is that it can be delivered at different levels of sophistication. This presupposes that technical and vocational education institutions can respond to the different socio-economic and academic backgrounds and prepare the participants for general employment and sustainable livelihoods.

Thus, the youth, the poor and the vulnerable of society can benefit from vocational/technical education. They stress that meeting the training needs of the prospective trainees of the National Directorate of Employment is what makes the training programme of the NDE relevant to the plights of the unemployed. NDE training programmes are created and maintained to enable people to make changes in their way of living and making a living. Thus, the NDE has a laid down procedure for enlisting who actually needs its training programmes so as to achieve the objectives of self-employment and employment generation in Nigeria (Adebayo, 2006, Bright and Carlo, 2003, Coombs, 2003).

\subsection{Government and Entrepreneurship Development Initiatives}

Over the years, governments in Nigeria have shown concern over the issue of entrepreneurship development and employment generation through small enterprises otherwise known as Micro, Small and Medium Enterprises (MSMEs). This is because government knows how important the subsector is to the country's economy.

Credible stakeholders agree that a nurtured and well-structured MSME sector contributes significantly to employment generation, wealth creation, poverty reduction and sustainable economic growth and development. Efforts made earlier by government to actualize MSME promotion failed until 2003 when the Small and Medium Scale Industry Development Agency (Establishment) Act, enacted by the National Assembly created the Small and Medium Industry Development Agency (SMIDA). The National Assembly passed the SMIDA amendment bill in December 2004. The Act changed the name of SMIDA to the Small and Medium Enterprises Development Agency of Nigeria (SMEDAN).

The Agency is today, the nation's apex institution with the statutory responsibility of facilitating the creation, resuscitation and stimulation of the growth and development of the MSMEs sector of the Nigerian economy. The establishment 
INDEPENDENT JOURNAL OF MANAGEMENT \& PRODUCTION (IJM\&P)

http://www.ijmp.jor.br

v. 6 , n. 3, July - September 2015

ISSN: 2236-269X

DOI: 10.14807/ijmp.v6i3.308

of SMEDAN is a giant stride by the Federal Government in repositioning the sector and realigning it into mainstream of the Nigerian economy. Government through the CBN launched the micro finance policy, regulatory and supervisory framework for Nigeria in 2005.

The policy provides the legal and regulatory framework for microfinance banking in Nigeria. The objective is to create a sustainable and credible microfinance bank capable of mobilizing and channelizing funds to the MSME subsector. Government again came up with the Small and Medium Enterprises Equity Investment Scheme (SMEEIS) initiative in response to its concerns and policy measure towards the aggressive and radical transformation of the subsector through the provision of adequate and cheaper funding.

With SMEEIS commercial banks operating in Nigeria are required to set aside 10 percent of their profit after tax (PAT) for equity investment in small and medium enterprises in Nigeria. The cumulative sum set aside by the banks under the scheme as at December 2009 was N42bn. To promote entrepreneurship and employment generation there are other government intervention programmes like the N200billion Small and Medium Scale Enterprises Guarantee Scheme (SMECGS) established in 2010 to fast track the development of the sector and set the pace for the industrialization of the economy and increase access to credit by small and medium enterprises and entrepreneurs.

Government also came up with the Train to Work (TRATOW) initiative, which is targeted at equipping young Nigerians with the skills required to establish and manage their small businesses. The MSME subsector has been experiencing some skill gaps necessary to grow the sector. This initiative is expected to close such gaps and lead to the establishment of new enterprises and the expansion of existing ones. Another model of promoting entrepreneurship by government is the Youth Enterprise with Innovation in Nigeria (YOU WIN) programme.

You Win programme is a collaboration of the Ministry of Finance, the Ministry of Communication and the Ministry of Youth Development that aims at encouraging aspiring, young entrepreneurs in Nigeria. This is in line with the Federal Government's drive to create more jobs for Nigerians. The programme is being 
INDEPENDENT JOURNAL OF MANAGEMENT \& PRODUCTION (IJM\&P)

http://www.ijmp.jor.br

v. 6 , n. 3, July - September 2015

ISSN: 2236-269X

DOI: 10.14807/ijmp.v6i3.308

implemented in partnership with the private sector that is mandated to provide the funding support. (MOMOH, 2012, AGBANUS, 2012, NDUMANYA, 2012).

The Federal Government believes that patronizing made-in-Nigeria goods will boost the nation's manufacturing sector and by extension create jobs. It aims at transforming the various sectors of the economy as well as providing the enabling environment including infrastructure, with a view to ensuring the nation's socioeconomic growth and development.

Lessons from other countries studies show that SMEs in both advanced economies and developing economies play key roles in employment generation. SMEs employ a substantial number of people in developing countries across the globe. Few examples are the clusters of handicraft enterprises in Vietnamese villages, which are being transformed through the development of new products or more advanced production techniques.

Researchers also argue that Turkish growth in the last decade has relied heavily on SMEs, whose dynamism derives from profitability and flexible labour markets. In view of the importance of entrepreneurship in employment generation and economic growth, the European Commission has launched a blueprint to unleash Europe's entrepreneurial potential and remove existing obstacles and to revolutionize the culture of entrepreneurship in Europe. The European Entrepreneurship Action Plan mainly involves encouraging member states to help increase investment readiness of entrepreneurs and SMEs and help businesses to fully benefit from the single market and access to markets in third world countries (ADEYEMI, 2014, UGOANI; NWAUBANI, 2014).

The challenges of unemployment continue to vibrate around the globe. According to Sami (2012) ILO warns that the global employment situation is "alarming", and contends that it is unlikely that the world economy will grow at a sufficient pace over the next couple of years to both close the existing jobs deficit and provide employment for the more than 80 million people expected to enter the labour market during this period. ILO believes that what is needed is growth and employment strategy.

And to pursue this strategy, multinational bodies like UNIDO are giving attention to entrepreneurship development and employment generation in 
INDEPENDENT JOURNAL OF MANAGEMENT \& PRODUCTION (IJM\&P)

http://www.ijmp.jor.br

v. 6 , n. 3, July - September 2015

ISSN: 2236-269X

DOI: 10.14807/ijmp.v6i3.308

developing economies of the world. According to UNIDO Country Representative in Nigeria, Ebonyi State Government had shown the will to move its people out of poverty, a situation, which led to the inauguration of some projects such as the Abakaliki Power Plant, the UNIDO Efficient Rice Mill, ICT Graduate Entrepreneurship Training Gasification Plant, Village Solar Lighting, and Salt Processing (KORMAWA, 2012).

Government claims to have created $17 \mathrm{~m}$ jobs so far. The minister of Trade and Investment states that there are over 17,284,681 sustainable enterprises in Nigeria. Each entity is expected to employ at least one Nigerian, thus creating over 17 million jobs through the MSMEs. According to the minister, the government recognizes that lack of access to market opportunities, lack of business development skills and the lack of consistency in government policies were the bane of MSMEs. What the government has done over the years in terms of entrepreneurship development programmes epitomized by the NDE amounts to nothing more than trying to formulate a sustainable "growth and employment" strategy to wedge the tide of alarming unemployment growth rate.

\section{RESEARCH METHODOLOGY}

The survey research design was employed for the study. Surveys refer to an investigation into certain things or events that exist or occur at the time of the research and connected with some problem situations that is felt over a wide area with a view to ascertaining what exists at the time of the research in their natural settings. Surveys are not characterized by manipulations and controls that dominate experimental studies. Populations involved in surveys are usually large. Surveys are oriented towards ascertaining and establishing the status quo, facts, or pieces of information at the time of the research and presenting such facts as they are or going further to analyse. Therefore surveys, could either be descriptive or analytical (OBODOEZE, 1996).

\subsection{Population and sample}

The target population comprises of a cross section of self-employed people clustered around Osisioma Local Government Area in Aba Zone. Aba Zone has the highest number of entrepreneurs in South East Nigeria. The sample was selected 
INDEPENDENT JOURNAL OF MANAGEMENT \& PRODUCTION (IJM\&P)

http://www.ijmp.jor.br

v. 6, n. 3, July - September 2015

ISSN: 2236-269X

DOI: 10.14807/ijmp.v6i3.308

based on the simple random sampling method, while the sample size was determined using the Yamane's technique.

\subsection{Data Collection Procedure}

Primary data were collected through a 20-item questionnaire designed along a 5-point Likert-type scale with numeric values ranging from 1-5. Secondary data were generated through books, journals, reports, gazettes, newspapers, etc. all the questions raised and information generated were on the relevance of NDE, entrepreneurship and employment generation. The two methods of data collection were used so as to complement, supplement, and validate data through each other. Data generated were organized, distilled and coded before they were classified.

\subsection{Data Analysis}

Data were analysed by Pearson's product moment correlation using the Statistical Package for the Social Sciences. The method was used in an attempt to determine the degree of relationship between entrepreneurship development and employment generation based on the NDE model.

\section{RESULTS AND INTERPRETATION}

\section{CORRELATIONS}

NARIABLES=ED: EG

/PRINT=ONETAIL NOSIG

ISTATISTICS DESCRIPTIVE

/MISSING=PAIRWISE.

\section{Correlations}

[DataSet0)

Table 1: Descriptive Statistics

\begin{tabular}{|l|l|l|l|}
\hline Variables & Mean & Std. Deviation & $\mathrm{N}$ \\
\hline Entrepreneurship development & .04 & 1.251 & 5 \\
Employment generation & 6.48 & 2.253 & 5 \\
\hline
\end{tabular}

Table 2: Correlations

\begin{tabular}{|lc|r|r|}
\hline Variables & $\begin{array}{r}\text { Entrepreneursh } \\
\text { ip development }\end{array}$ & $\begin{array}{l}\text { Employment } \\
\text { generation }\end{array}$ \\
\hline Entrepreneurship development & Pearson's & 1 & $.901^{*}$ \\
Correlation & Sig. (1-tailed) & 5 & .018 \\
& $\mathrm{~N}$ & 5 & 5 \\
\hline Employment generation & Pearson's Correlation & $.901^{*}$ & 1 \\
& Sig. (1-tailed) & .018 & 5 \\
& $\mathrm{~N}$ & 5 & 5 \\
\hline
\end{tabular}




\section{* Correlation is significant at the 0.05 level (1-tailed).}

Statistical result in table 2 showed coefficient of correlation $r=.901^{*}$, suggesting that there is a "strong" positive relationship between entrepreneurship development and employment generation. This result is splendid rather than an overstatement as it is in tandem with the popular views in Nigeria.

For example Adeyemi (2014) states: "Correspondingly, it is held that MSMEs account for over 90 percent of Nigeria's businesses. Some common examples of these MSMEs are, canteens or restaurants, shops, complexes and plazas that we use for our offices, relaxation joints, hotels, brothels, kiosks, sales outlets and a host of other such places we dress up to go daily in order to make our ends meet". In view of this statistical result, the hypothesis that states that entrepreneurship development has no relationship with employment generation was rejected while the alternate hypothesis was accepted. This is the objective of the study.

\subsection{Discussion}

The NDE programme is consistent in the pursuit of various skill enhancement schemes in realization of the fact that entrepreneurship development and innovation is increasingly knowledge-and-skill-intensive. Fostering entrepreneurial innovation requires not only highly knowledgeable, experienced and skilled entrepreneurs but also highly skilled labour.

Thus, educational policies and capacity building are important public policies for entrepreneurship development. In realization of this situation, the National Universities Commission (NUC) in 2011 mandated all universities in Nigeria to mount B.Sc. programme in Entrepreneurship. The NUC sees a growing need for entrepreneurship educational system.

According to the NUC, government is cognizant of the necessity to imbue graduates with the mind set of enterprise and innovativeness in order to generate and realize new opportunities in the economy. Thus, integration of entrepreneurship studies into university education will prepare the youths to be responsible enterprising individuals who will become entrepreneurs or entrepreneurial thinkers and contribute to economic development and sustainable communities. The goal is to empower graduates, irrespective of their areas of specialization, with skills that will 
INDEPENDENT JOURNAL OF MANAGEMENT \& PRODUCTION (IJM\&P)

http://www.ijmp.jor.br

v. 6 , n. 3, July - September 2015

ISSN: 2236-269X

DOI: 10.14807/ijmp.v6i3.308

enable them engage in income yielding ventures if they are unable to secure paid employment.

It is a re-orientation from the take-a-job mentality to the make-a-job mentality. This approach is urgent because lack of employable skills is no doubt, a major contributing factor to the problem of unemployment worldwide and especially in Nigeria where about 42 percent of the total population of about $160 \mathrm{~m}$ are unemployed, and worse still, an estimated $67 \mathrm{~m}$ physically fit youths are also unemployed.

The situation is so today because the educational policy adopted at postindependence era in Nigeria places emphasis on liberal education rather than acquisition of vocational skills, which prepare the individual for alternative employment in the absence of government or any other type of paid employment choices. The philosophy of NDE is self-enterprise, which emphasizes selfemployment and self-reliance in preference to wage employment. Europe today believes that entrepreneurship education is key to sustainable economic upsizing.

Studies show that students who receive entrepreneurship education are not only more likely to be employed, but also more likely to start their own companies. With this in mind, the European Commission Plans to expose students to entrepreneurship and, as a result, help create jobs throughout Europe. Eurobarometer Entrepreneurship Survey shows that three quarters of Europeans have never taken part in an entrepreneurship course thus, in order to exploit the potential of entrepreneurship education and promote the entrepreneurship 2020 Action Plan, and ensure that the key competence in entrepreneurship is embedded into curricula across primary, secondary, vocational, higher and adult education before the end of 2015, and offer young people at least one practical entrepreneurial experience before leaving compulsory education.

\subsection{Recommendations}

i. Government should increase the funding of the NDE programme. This will enable it enhance the capacity of its skill centres for better training of participants. 
INDEPENDENT JOURNAL OF MANAGEMENT \& PRODUCTION (IJM\&P)

http://www.ijmp.jor.br

v. 6, n. 3, July - September 2015

ISSN: 2236-269X

DOI: 10.14807/ijmp.v6i3.308

ii. NDE should spread to the different communities instead of concentrating on the urban centres. This is needed so as to catch up with more pupils and students in the rural areas for entrepreneurship skills acquisition.

iii. The healthy and active poor should be encouraged to participate in NDE programmes. This will afford them the opportunity of self-employment.

iv. Government should mandate all the 774 local government areas in Nigeria to create NDE farms in their areas. This will not only enhance food production but also provide more employment in the agricultural sector.

v. The NDE should explore the need for a MoU with their main bankers for the finance of their accredited projects. This will help participants in NDE Programmes who have the necessary skills and appetite to start their own businesses.

\subsection{Scope for further study}

Further study should examine the relationship of experience and small business failures. This will help in finding a solution to the problem of cessation of such enterprises shortly after taking off.

\section{CONCLUSION}

The NDE remains one of the programmes of the Federal Government of Nigeria aimed at employment generation. It has generated about $1.90 \mathrm{~m}$ employment since inception between 1987 and 1996, and also created 177,168 new employments in the last two years. While unemployment is a subject we are all familiar with there is a growing body of empirical evidence that skill acquisition and youth empowerment and employment are about the surest ways of generating opportunities and reducing unemployment.

The reason behind setting up the Chukwuma Committee that produced the blueprint for the introduction of the NDE was not unconnected with a decline in the fortunes of the Nigerian economy, which resulted to a desperate and alarming rate of unemployment. Thus, the NDE can safely be regarded as the catalyst of employment generation in Nigeria.

Other skill acquisition programmes like the entrepreneurship initiative of the NUC, the European Commission Entrepreneurship 2020 Action Plan, and the 
INDEPENDENT JOURNAL OF MANAGEMENT \& PRODUCTION (IJM\&P)

http://www.ijmp.jor.br

v. 6 , n. 3, July - September 2015

ISSN: 2236-269X

DOI: 10.14807/ijmp.v6i3.308

Subsidy Reinvestment and Empowerment Programme (SURE-P) Graduate Internship Scheme (GIS) reflect the common features of the NDE. For example, in 2014 over 150,000 graduates registered for the SURE-P Scheme across Nigeria while over 7,000 firms signed up to take in interns. 962 interns successfully took part in the programme.

In furtherance of its efforts towards tackling unemployment, addressing issues of poverty and vulnerability and promoting inclusive finance at the grass-root levels, the NDE tailored a new scheme called Special Micro Empowerment Scheme (SMES), which is aimed at promoting social inclusion and job creation. The micro enterprises being promoted include: Akara and kunu making potatoes/plantain frying, vegetable oil extraction, pure water/beverages sales, vegetable/fruits sales, shoemaking, shining among other vocations.

Today MSMEs like these account for about 99.6 percent of registered businesses in Nigeria by which about 63 percent of the labour force earn a living. About 35.7 percent of the total sales and value added in the manufacturing sector come from the MSMEs as well. To reduce the problems of low finance in the MSMEs sector the NDE is promoting financial inclusion to ensure that efforts at employment generation are not hindered. With $r,=.90$, the study found that NDE contributes to the creation of employment and wealth and also provides the Nigerian economy with a continuous supply of ideas, skills, and innovations necessary for the efficient management of enterprises and scarce resources. The NDEs one million job creation programme remains a wonderful idea in employment generation.

\section{REFERENCES}

ADAM, S.; NAUDE, W.; GOEDHUYS, M. (2011) Entrepreneurship, Innovation and Economic Development. Netherlands Oxford University Press.

ADEBAYO, A. A. (2006) Youth, Unemployment and the National Directorate of Employment Self-Employment Programmes Nigeria - Journal of Economics and Social Studies, v. 41, n. 1, p. 81-102.

ADEBISI, T. A.; ONI, C. S. (2012) Assessment of relevance of the National Directorate of Employment (NDE) Training Programmes to the Needs of the Trainees in South Western Nigeria. International Journal of Vocational and Technical Education. V. 4, n. 3, p. 29-37.

ADEYEMI, A. (2014) Sidelining of Corporate Social Responsibility by MSMEs. The Guardian, v. 31, n. 13138, p. 80. 
INDEPENDENT JOURNAL OF MANAGEMENT \& PRODUCTION (IJM\&P)

http://www.ijmp.jor.br

v. 6, n. 3, July - September 2015

ISSN: 2236-269X

DOI: 10.14807/ijmp.v6i3.308

AGBANUS, N. (2012) Doing What You Like and Promoting the Economy. Eseoghene Odiete Businessday, v. 10, n. 218, p. 35.

AGBOOLA, T. (2012) Over $1.4 \mathrm{~m}$ jobs created in 12 months says Aganga. The Nation, v. 7, n. 2157, p. 13.

AGANGA, O. (2012) Patronising Made in Nigeria Goods Will Boost Manufacturing Aganga Businessday, v. 10, n. 218, p. 36.

AGANGA, O. (2013) FG Generates N9bn Funding Pool for MSMEs. National Daily, Edition 407, p. 14.

AFOLABI, B. (2014) Business/SME Report. The Nation, v. 8, n. 2733, p. 64.

AKANWA, P.U AND AGU, C.N (2005) Entrepreneurship Theory and Practice in Nigeria, Owerri. Resource Development Centre.

AKANWA, P. U. (2006) The Making of the Industrial Man Owerri, Global Press

BRIGHT, P.; CARLO VAN, I. (2003) Environmental Education and Training in the Royal Dutch/Shell Group of Companies UNEP Industry and Environment. p. 2831.

COOMBS, P. N. (2009) New Path to Learning for Rural Children and Youths.

International Commercial on Education. p 14-15.

DEBELAK, D. (2006) The Risk-Free Entrepreneur: The Idea Person's Guide to Building a Business with Other People's Money, USA, Adams Media.

EUROPEAN COMMISSION (2013) Entrepreneurship as a Main Driver for Economic Growth. MEMO/13/5, Brussels.

FEDERAL GOVERNMENT OF NIGERIA (1986) Chukwuma Committee Report on NDE.

FEDERAL GOVERNMENT OF NIGERIA (2010) Small and Medium Scale Enterprises Guarantee Scheme.

FEDERAL GOVERNMENT OF NIGERIA (2003) Small and Medium Industries Development Agency (Establishment) Act.

HOFER, C. W.; CHARAN, R. (1984) ADAM, S.; NAUDE, W.; GOEDHUYS, M. (2011) Entrepreneurship, Innovation and Economic Development. Netherlands Oxford University Press. American Journal of Small Business, Summer $1984=3$.

ISIMOYA, O. A. (2012) Nigerian Graduates and Entrepreneurial Opportunities.

Business Day, v. 10, n. 218, p. 13.

KORMAWA, P. (2012) UNIDO to establish Cassava Processing Plant in Oyo State Nigerian Pilot, v. 2, n. 154, p. 30.

LEAP AFRICA (2006) Defying the Odds: Case Studies of Nigerian Organizations, That Have Survived Generations. Lagos, Leap Africa.

MASARI, A. B. (2014) National Enterprise Development Programme to Provide $5 \mathrm{~m}$ jobs by 2015. Leadership, n. 2127, p. 25.

MATANMI, O. O. (2006) The Nexus of Entrepreneurial Spirit and Sustainable Enterprise Development. Lagos Organisation Review, v. 2, n. 14, p. 5-7. 
INDEPENDENT JOURNAL OF MANAGEMENT \& PRODUCTION (IJM\&P)

http://www.ijmp.jor.br

v. 6, n. 3, July - September 2015

ISSN: 2236-269X

DOI: 10.14807/ijmp.v6i3.308

MOMOH, S. (2012) The Problem with Small Enterprises. Businessday, v. 10, No. 218, pp. 31-34.

MOSES - ASHIKE, H. (2012) MFBs set to disburse N600m to small holder farmers Business Day, v. 10, n. 218, p. 28.

NDUJIHE, C. (2015) How Govt Created $17 \mathrm{~m}$ jobs - Aganga. Vanguard, v. 25, n. 62332, p: 8.

NDUMANYA, N. (2012) Removing Obstacles to Firm Growth, Prerequisite to Foster Entrepreneurship - Report Businessday, v. 10, n. 218, p. 35.

NZENWA, S. O. E. (2000) Micro-Credit and Development: Poverty Alleviation in Nigeria Lagos. Centre for Development and Civic Education.

OBODOEZE, F. O. (1996) Modern Textbook of Research Methodology, Enugu, Academic Publishing Company.

OGUNDELE, D. (2006) Entrepreneurship Studies and Development in Nigeria: The Missing Link. Lagos Organization Review, v. 2, n. 4, p. 69-74.

OKENWA, C. P. (1999) Entrepreneurship Development in Nigeria - A Practical Approach. Onitsha, Adson Education Publishers.

OKOJIE, J. (2011) National Universities Commission: Bench Mark Minimum Academic Standards For Undergraduate Programmes In Nigerian Universities, NUC, Abuja.

OLAYINKA, C. (2014) National Directorate of Employment to Establish Agric Park. The Guardian, v. 31, n. 13136, p. 31.

ONYEKAKEYA, L. (2014) CBN's Strategic Failure in Micro Finance Banking. The Guardian, v. 30, n. 12850, p. 13.

OSEHOBO, V. (2012) 67 million Youths Unemployed - Minister Nigerian Pilot, v. 2, n. 154, p. 1-2.

OTABOR, O. (2014) Oshiomhole gets Lawmakers nod to access CBN's N2b. The Nation, v. 9, n. 3069, p.53.

OTTI, S. (2014) Unemployment Drain Nigerian Economy Anyaoku, Daily Sun, v. 10, n. 3033 , p. 9

SAMI, D. (2012) ILO Warns Global Employment Situation is "Alarming"

Nigerian Pilot v. 2, n. 154, p. 35.

SNYDER, C. A.; MANZ, C. C.; LAFORGE, R. W. (1983) Self-Management: A key to Entrepreneurial Survival American Journal of Small Business. July September, $1983=20-26$.

STEVENSON, H.; GUMPERT, D. E. (1985) The Heart of Entrepreneurship. Harvard Business Review, March-April 1985:85.

UGOANI, J. N. N.; NWAUBANI A. N. (2014) Entrepreneurship Education as Helicopter for Entrepreneurship Development. Nigeria Perspective. International Journal Management Sciences, v. 4, n. 4, p. 182-198

UWAZIE, I. U. (2006) Labour Economics A Comprehensive Approach Owerri, Publish + Print Peace wise Systems. 
INDEPENDENT JOURNAL OF MANAGEMENT \& PRODUCTION (IJM\&P)

http://www.ijmp.jor.br

v. 6, n. 3, July - September 2015

ISSN: 2236-269X

DOI: 10.14807/ijmp.v6i3.308

WORLD BANK (2009) Banking the Poor. Measuring Banking. Access in 54 Economics. The World Bank Washington, D.C. 